\title{
Hydrological modelling of the "Sierra de las Minas" in Guatemala, by using a conceptual distributed model and considering the lack of data
}

\author{
M. Morales-de la Cruz \& F. Francés \\ Department of Hydraulics Engineering and Environment, \\ Polytechnic University of Valencia, Spain
}

\begin{abstract}
The Biosphere Reserve "Sierra de las Minas" is part of the Guatemalan System of Protected Areas and contains the largest cloud forests of Guatemala. Its southern slopes flow into the Motagua Valley, one of the more active zones in the country and paradoxically, the most arid and driest zone of Central America. We have studied the hydrology of the Teculután Basin on a daily time step, by estimating its hydrological characteristics and using the conceptual distributed model Tetis v. 7.2 developed at the Polytechnic University of Valencia, Spain. We applied a new split-parameter structure coupled with the SCE-UA automatic optimization algorithm to obtain the set of optimal correction factors of the model. Among the results we have completed a precipitation spatial and sensitive analysis. The model has shown a high sensitivity to changes in the parameter, which characterizes the precipitation increment due to the difference in altitude. In an attempt to capture seasonal variability produced by the presence of the cloud forest in the upper portion of the basin, we studied the horizontal precipitation and the sensitivity to changing the correction factor for evaporation and the vegetation cover index.
\end{abstract}

Keywords: distributed hydrological model, automatic calibration, conceptual model, Sierra de las Minas, cloud forest.

\section{Introduction}

In Central America, the study of the hydrological cycle in mountain basins has had different approaches, mostly monthly or annual water balances or only 
descriptive studies. However the lack of available data at basin scale is a critical factor that denies answers to key questions of hydrological processes.

Availability of hydroclimatic, edaphologic and geologic data is the main restraint to understanding the complex hydrology of the basins in Sierra de las Minas. Albeit recent advances in climate variables have been achieved in micro basins, there are still large uncertainties. This is one of the first successful attempts in Guatemala in applying a hydrological model on a daily basis, and the first in this natural reserve with a distributed model. This is a strategic achievement for Central American water resources research and management, considering the common lack of available data in the region.

\section{Study site and basin characteristics estimation}

The Sierra de las Minas is located in eastern Guatemala. The regional precipitation changes as a response to the oriented mountain range from the east to the lowest elevations in the west. Prevailing winds are from the north-east, and the mountains create a rain shadow for the southern slopes that drains to the Motagua River [1, 4, 8]. Complete meteorological and hydrological data for the southern slopes tributaries of the Motagua River is unusual. Based on field knowledge and technical advice from institutions and different experts, we have concentrated our data search on the southern slope of the reserve, between Hato and Río Hondo Basins, in the departments of Zacapa and El Progreso. Within this approximately $950 \mathrm{~km}^{2}$ zone, there are just four meteorological and three flowgauge stations with available data and a register period greater than five years from 1990-2004 when meteorological and flow available data coincide. This means an average coverage of $237 \mathrm{~km}^{2} /$ station for climate and only three tributaries of Motagua River with a flow record among the study site. The stations are operated by the Guatemalan National Institute of Seismology, Volcanology, Meteorology and Hydrology and by the National Institute of Electrification. The registers are from different and not necessarily consecutive time periods, the variables are limited (mostly rainfall or temperature data), and there are irregularities in terms of continuous quality control.

The original digital elevation model (DEM) had a resolution of $20 \mathrm{~m}$. Nevertheless, to reduce the computational time during automatic calibration and because of the scale of the rest of the spatial information available, the final cell size adopted was $100 \mathrm{~m}$. The digital information concerning geology and land cover at the scale of 1:50,000 is partially available for the study site. The only basin within the study site with daily flow record and soil information at this scale is Teculután Basin, but it does not have rainfall nor temperature stations within its basin. However, the extrapolation of near basins data is a common practice in studies on the reserve [12]. We estimated the potential evapotranspiration (PET) by using the Hargreaves equation adapted to Guatemala for the lowest station of the basin (the only one with daily relative humidity values), and only for temperature stations (the middle and highest), the Thorntwaite equation and a correction factor adjusted by simple comparison between both methods. 
The estimation of the hydrological characteristics maps for each cell gives values close to areal mean point scale estimations. A simple and efficient method was used for parameter maps estimation [11].

Capillary water storage, saturated upper soil hydraulic conductivity, $k_{s}$, and saturated deep soil hydraulic conductivity, $k_{p}$, have been estimated from the vegetation, soil and geology study by SINAFIP and EDESA [12]; this estimation is done for each cartographic unit of the soil map.

\section{TETIS model and automatic calibration}

The used model is conceptually based, simulates all the main components of the land phase of the hydrological cycle, and it is distributed in space using a regular grid. It has been developed by our research group during the last ten years, with good results in different climatic and catchment size scenarios and for floods and continuous simulation related problems $[5,13]$. The proposed conceptualization in TETIS for runoff production at each cell consists of five vertical tanks, each one representing the different water storages in an "extended soil column". The tanks are called: static, surface, gravitational, aquifer and snow cover (in special cases). The vertical and horizontal connections between tanks describe the different movements of water $[6,13]$.

Parameters in any model are intended to express numerically the main characteristics of the catchment from the perspective of the model. Francés et al [6] have proposed to split the effective parameter at each cell in two components: the hydrological characteristic (at point scale and maintaining its physical meaning) and the correction factor (common for all cells and taking into account all modelling errors including the temporal and spatial scale effects). The optimization algorithm selected for the automatic calibration was the so-called SCE-UA method. In this work the Root mean square error (RSME) at the daily scale was used as the objective function for the optimization algorithm; but the graphical analysis, the Nasch and Sutcliffe model efficiency coefficient and the balance error, at daily scale are used for evaluation criteria during the calibration and validation periods. With the split-parameter structure only a limited number of correction factors need to be calibrated. For the TETIS model this number is only nine, but other variables can be included in the calibration process, such as the initial condition of the state variables. We have included the coefficient $\beta$ in the calibration process to cater for precipitation increasing with altitude and for the lack of good spatial estimation of the precipitation at the selected time discretization [6].

\section{Cloud forests and hydrological processes}

Research community has enhanced its interest in the role of cloud forests $(C F)$ on hydrological processes since the eighties, but until present, fog inputs and horizontal precipitation are notoriously difficult to quantify. Because fog water and near-horizontal wind-driven rain could not be separated their sum is henceforth referred to as horizontal precipitation, HP. Substantial amounts of 
HP that largely bypasses traditional rain gauges [2, 3]. HP occurs when fog intercepted droplets coalesce on foliar and woody surfaces and drip to the forest floor as fog passes through the forest canopy $[8,9]$.

In Central America, the northeast trade winds carry moisture from the Caribbean Sea to mountain ridges and in the Sierra de las Minas, a type of CF is generally found between 1400 to 2700 m.a.s.1. [1, 10]. In general, fog interception increases with altitude (in the same mountain), exposure (wind-ward slopes) leaf inclination, and is often inversely related to precipitation and influenced by local topography. There is as yet no hard published evidence to suggest that dry season flows in Central America are indeed declining as a result of cloud forest conversion $[1,3]$; one study of this conversion results was made for the Sierra de las Minas [1], but the evidence is inconclusive considering its methodology limitations [2].

\subsection{Estimation of horizontal precipitation, HP}

In Guatemala, the cloud forests have typically few if any raingauge stations, and considering that the measurement of horizontal precipitation is still in the research mode, no daily climatological records are available. Horizontal precipitation is not equal to the difference between incident precipitation and throughfall because evaporation of water and canopy storages during the process of interception are not accounted for in the equation [8,9]. In our study $H P$ is calculated with an adapted expression of Frumau et al [7]:

$$
H P_{t}=T f_{t}+E_{\text {int }_{t}}+S f_{t}-P P_{t}
$$

where for the day $\mathrm{t}, T f_{t}$ is the throughfall, $E_{\text {int }_{t}}$ is the interception evaporation, $S f_{t}$ is the Stemflow, $P P_{t}$ is the gross precipitation.

Vegetation parameterization within the cloud forest belt of Sierra de las Minas is based on values taken from different studies [1, 8, 9] and literature review. Available weekly measurements of $T f_{t}$ and $P P_{t}$ and 'apparent fog interception (FI)' are found in Holder [8, 9] for the period 24 July 1995 to 7 June 1996, which coincides with our calibration period; the preliminary work of Brown et al [1] suggests that stemflow accounts for $<2 \%$ of the hydrological inputs to the $\mathrm{CF}$ in the reserve. $E_{\text {int }}$ was estimated assuming it decreased linearly with decreasing actual moss water content, going from the maximum rate for saturated vegetation $\left(\mathrm{E}_{\max }\right)$ to zero for fully dry vegetation like in the study of Hölscher et al [10]:

$$
E_{\text {int }_{t}}=\left(S_{\max }-S_{t} / S_{\max }\right) E_{\max }
$$

where $\mathrm{S}_{\max }$ is the maximum canopy storage capacity, $S_{t}$ is canopy storage capacity on the day $t$, and $\mathrm{E}_{\max }$ correspond to our estimated potential ET. Storage capacity values $\left(S_{t}\right.$ in $\left.\mathrm{mm}\right)$ on a daily time step moves between zero for a saturated vegetation and $S_{\max }$, and was estimated with an adapted expression of Hölscher et al [10]:

$$
S_{t}=\max \left[0, \min \left[S_{\max }, S_{t-1}+E_{\text {int }_{t-1}}-P P_{t}-F I_{t}\right]\right]
$$


In cases of low data availability a simple regression equation is often used to describe interception and canopy storage capacity has been determined as the mean intercept of the regression lines of measured rainfall vs. throughfall [10]. For the reserve the estimated value $S_{\max }$, given by Holder [9] is $11.03 \mathrm{~mm}$. The fog also suppresses evaporation [7].

In evaporation simulation for Costa Rica, during times of fog and HP a value of $100 \%$ humidity was used [3]. That is the reason why we analyzed the sensitivity to changes in the correction factor of evapotranspiration and vegetation cover index in TETIS model.

\section{Results and discussion}

\subsection{Model calibration}

Our range of feasible values for the variables to be calibrated has been estimated by personal experience and from values obtained with a first manual calibration. With the split-parameter structure used [6], it is possible to find a general search range for correction factors, mainly because the scale effects and errors can be predicted. Adopting these possible maximum search ranges, the optimization process using the SCE-UA algorithm was performed for the Las Minas flowgauge station (at Teculután Catchment) using the mean of each range as initial value for two cases: without estimation of horizontal precipitation (optimum A) and with its estimation (optimum B). The calibration period is from $01 / 01 / 1995$ to $31 / 12 / 1996$. The results are presented in Table 1.

Since the simulated base flow was performing according to our expectations, for optimum B we just optimized static storage, infiltration, evapotranspiration and specially precipitation factors. The water balance obtained was (in $\mathrm{mm} /$ year): precipitation 2570.56; evapotranspiration (ET) 1318.52; PET 1390.27; observed discharge 998.16; simulated discharge 920.16.

Moreover, the a priori knowledge of the catchment dictates that the base flow and the interflow must be the most important source of the river discharge. For our simulation with optimum B, interflow represents the $30.44 \%$ of the total discharge, base flow the $55.86 \%$ and direct runoff the $13.74 \%$ of it.

\subsection{Precipitation spatial analysis}

The model has shown high sensitivity to changes in the parameter $\beta$, which characterizes the precipitation increment due to the difference in altitude. Results in Table 2 show that this parameter has a great impact on the water balance.

One of the main sources of uncertainty in the Sierra de las Minas is the input precipitation data, especially about its highest altitudes and the difficulty to quantify horizontal precipitation contributions. In our study site, input precipitation data pertains to near basins and the highest rain gauge station has an altitude of just $1900 \mathrm{~m}$ a.s.l. (the highest part of Teculután basin is near $3000 \mathrm{~m}$ a.s.1.). This is the reason why we first analysed the mean increments of precipitation with altitude and the results of which (Table 3) show good agreement between the calculated mean rate of increment for field measurements $(1.41 \mathrm{~mm} / \mathrm{m})$ and the one for simulations $(1.39 \mathrm{~mm} / \mathrm{m})$. 
Table 1: $\quad$ Search range and optimum A and B results found by the SCE-UA algorithm. Initial storages $\mathrm{H} 2$ and $\mathrm{H} 3$ were fixed to $0, \mathrm{H} 1$ to $20 \%$ and $\mathrm{H} 4$ to $40 \mathrm{~mm}$. R4 was fixed to 0 , and for optimum B, R5 to R9 to values of optimum $\mathrm{A}$.

\begin{tabular}{|c|c|c|c|c|}
\hline Correction factor & $\begin{array}{l}\text { Lower } \\
\text { limit }\end{array}$ & $\begin{array}{l}\text { Upper } \\
\text { limit }\end{array}$ & Optimum A & Performance indexes \\
\hline R1 Static storage & 0.7 & 1.5 & 0.76807 & \multirow{9}{*}{$\begin{array}{c}\text { RMSE: } 7.28 \text {; Balance } \\
\text { error (\%) 4.4; Daily } \\
\text { Nash and Sutcliffe } \\
\text { coef. (E): } 0.12\end{array}$} \\
\hline R2 Evapotranspiration & 0.8 & 1.5 & 1.10567 & \\
\hline R3 Infiltration & 0.05 & 0.3 & 0.09913 & \\
\hline R5 Percolation & 0.01 & 0.5 & 0.08736 & \\
\hline R6 Interflow & 100 & 800 & 701.96704 & \\
\hline $\begin{array}{l}\text { R7 Groundwater } \\
\text { outflow }\end{array}$ & 0 & 5 & 0.10047 & \\
\hline R8 Base flor & 5 & 20 & 5.00066 & \\
\hline $\begin{array}{l}\text { R9 River channel } \\
\text { velocity }\end{array}$ & 0.5 & 1.5 & 1.0236 & \\
\hline$\beta$ Precipitation & 0 & 0.05 & 0.00739 & \\
\hline Correction factor & $\begin{array}{l}\text { Lower } \\
\text { limit }\end{array}$ & $\begin{array}{l}\text { Upper } \\
\text { limit }\end{array}$ & Optimum B & Performance indexes \\
\hline R1 Static storage & 0.7 & 1 & 0.998 & \multirow{4}{*}{$\begin{array}{l}\text { RMSE: 7.06; Balance } \\
\text { error (\%) 7.81; Daily } \\
\text { Nash and Sutcliffe } \\
\text { coef. (E): } 0.17\end{array}$} \\
\hline R2 Evapotranspiration & 0.9 & 1.2 & 1.1998 & \\
\hline R3 Infiltration & 0.08 & 0.1 & 0.095 & \\
\hline$\beta$ Precipitation & 0.006 & 0.008 & 0.0063 & \\
\hline
\end{tabular}

Table 2: Performance indexes for simulations with change of correction factor " $\beta$ " and stable correction factors of optimum A. Data from Las Minas station, period 01/01/1995-31/12/1996.

\begin{tabular}{|c|c|c|c|c|}
\hline $\begin{array}{c}\text { Simulated } \\
\text { Precipitation } \\
\text { (mm/year) }\end{array}$ & $\begin{array}{c}\text { Correction } \\
\text { factor of } \\
\text { Precipitation } \\
\beta\end{array}$ & $\begin{array}{c}\text { Balance } \\
\text { Error (\%) }\end{array}$ & $\begin{array}{c}\text { Nash and } \\
\text { Sutcliffe } \\
\text { coefficient } \\
(E)\end{array}$ & RMSE \\
\hline 1787.83 & 0 & 31.233 & 0.11 & 7.655 \\
\hline 1851.85 & 0.001 & 29.069 & 0.11 & 7.646 \\
\hline 2303.23 & 0.00739 & 4.4 & 0.12 & 7.28 \\
\hline 2500.80 & 0.01 & -4.602 & 0.07 & 7.798 \\
\hline
\end{tabular}

Cloud interception is a highly seasonal process that assumes its greatest importance during the dry season and mostly upstream of dry areas [1-3], which is the case of the southern slopes of the Sierra de las Minas. As can be seen in Figure 1, in our simple estimation approach of horizontal precipitation by considering lack of local data (mostly canopy evapotranspiration rates of plant 
functional groups and uncertainties on daily interception) we have found similar evidences of cloud forest hydrological relevance during the dry season (middle November to the end of April).

Table 3: Precipitation increments with altitude $(\mathrm{mm} / \mathrm{m})$ for field data $(3$ raingauge stations) and simulations with optimum $\mathrm{A}$ (5 different altitudes). Data from 01/01/1995-31/12/1995.

\begin{tabular}{|c|c|c|c|c|c|c|c|}
\hline $\begin{array}{c}\text { Simulated } \\
\text { point }\end{array}$ & $\begin{array}{l}\text { Alt (m } \\
\text { a.s.l.) }\end{array}$ & $\begin{array}{c}P P \\
(m m / y r)\end{array}$ & $\begin{array}{l}\text { Simulated } \\
\text { Mean } \\
\text { Increment } \\
\text { Rate "PP } \\
/ \text { Alt" } \\
(\mathrm{mm} / \mathrm{m})\end{array}$ & Station & $\begin{array}{l}\text { Alt (m } \\
\text { a.s.l.) }\end{array}$ & $\begin{array}{c}P P \\
(m m / y r)\end{array}$ & $\begin{array}{c}\text { Field } \\
\text { Mean } \\
\text { Increment } \\
\text { Rate "PP } \\
/ \text { Alt" } \\
(\mathrm{mm} / \mathrm{m})\end{array}$ \\
\hline A & 1511.00 & 3047.09 & \multirow{5}{*}{1.39} & Albores & 1900.00 & 2423.30 & \multirow{3}{*}{1.41} \\
\hline B & 1020.00 & 2669.44 & & $\begin{array}{l}\text { San } \\
\text { Lorenzo }\end{array}$ & 1720.00 & 1779.50 & \\
\hline $\mathrm{C}$ & 668.00 & 2234.53 & & Pasabién & 260.00 & 1116.70 & \\
\hline D & 395.00 & 1751.89 & & \multirow{2}{*}{\multicolumn{4}{|c|}{$\begin{array}{c}\text { PP: precipitation; Alt: altitud. Simulation } \\
\text { made with Tetis v } 7.2 \text { hydrology model, by } \\
\text { using a correction factor of precipitation } \beta \\
=0.00739\end{array}$}} \\
\hline $\begin{array}{c}\text { Las } \\
\text { Minas } s t\end{array}$ & 300.00 & 1527.74 & & & & & \\
\hline
\end{tabular}

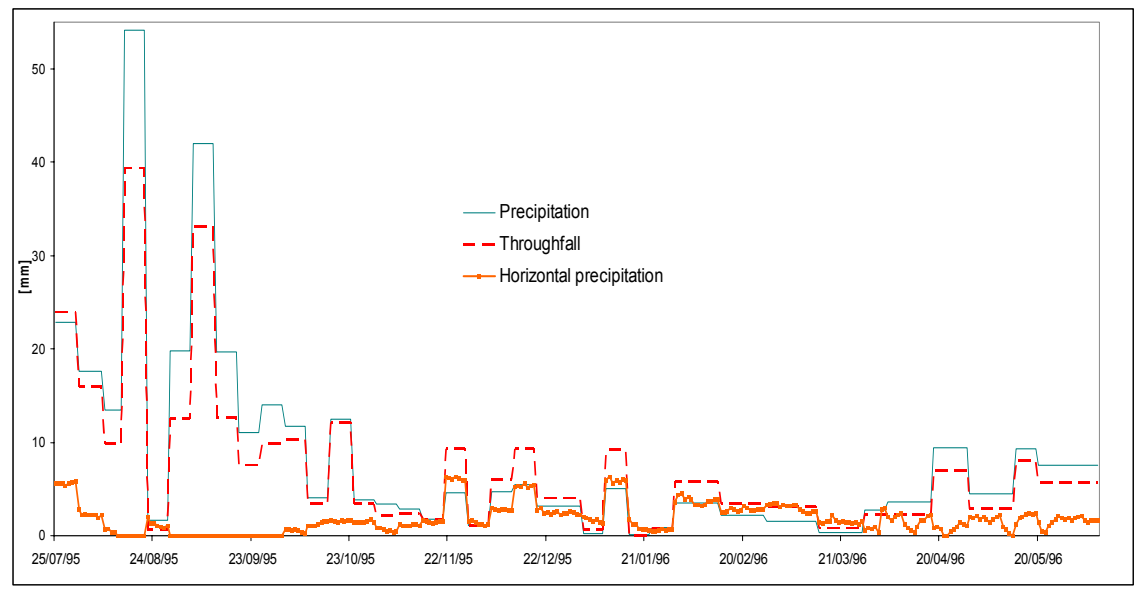

Figure 1: Daily horizontal precipitation estimated with a simple model and weekly records of throughfall and gross precipitation of a cloud forest in Sierra de las Minas.

The 44-week horizontal precipitation estimated is approximately $600 \mathrm{~mm}$. This value is within the range reported for water budget studies in cloud forest environments $[1,2,10]$. This data was included on its respective calibration date, and as well as an approximation for the validation period. 


\subsection{Model validation}

This process has the function of demonstrating that the dominant hydrological components in a particular catchment can been adequately simulated, and that the desired prediction performance can be reached [6]. Table 4 displays the significant variation in hydrological behaviour by using different correction factors, which shows a better performance for optimum B. Therefore the lack of information about water input data to the basin has been confronted by including a correction of factor $\beta$ (for the precipitation increment with altitude) and the daily horizontal precipitation estimations, and the analysis must strongly consider this facts.

Table 4: Performance indexes during the temporal validation period (01/01/1997-30/06/2003) for the optimum A and B.

\begin{tabular}{|l|c|c|}
\hline Performance index & Optimum A & Optimum B \\
\hline RMSE & 5.17 & 4.95 \\
\hline Balance Error (\%) & 8.66 & 10.38 \\
\hline Daily Nash and Sutcliffe coefficient (E) & 0.16 & 0.23 \\
\hline
\end{tabular}

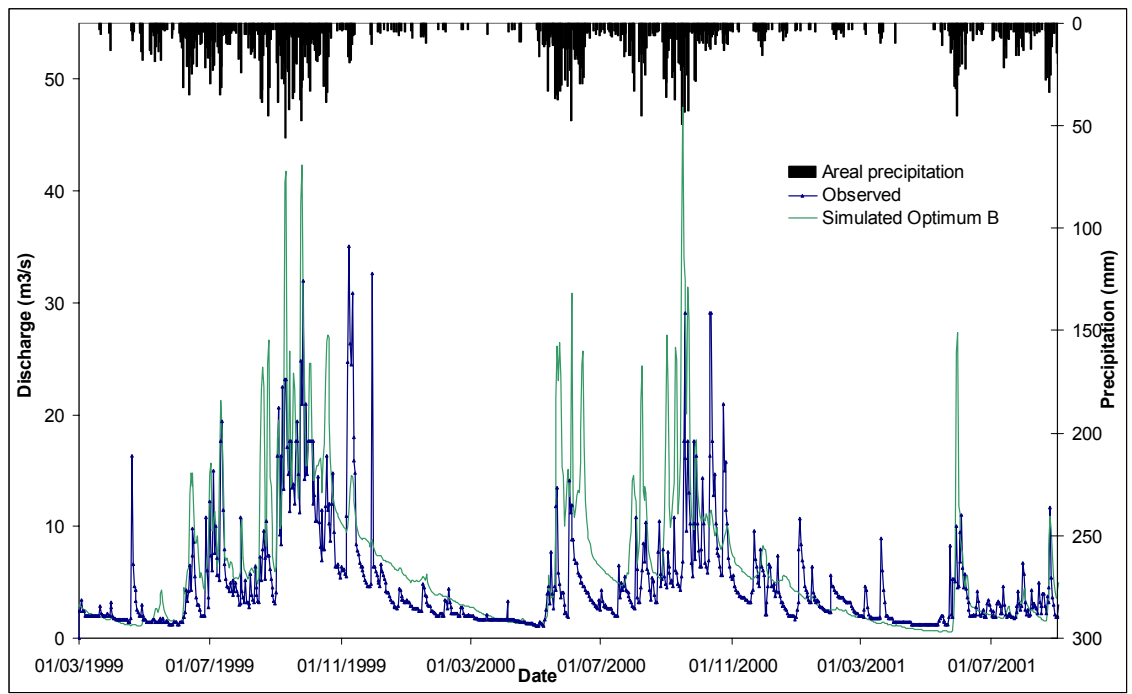

Figure 2: Results of simulated daily discharges at validation period (between 01/03/1999-31/08/2001) in Las Minas station, with optimum B.

For the Las Minas station, on the southern slopes of the Sierra de las Minas reserve, the validation is considered acceptable as can be seen with the analysis of the graphical results (Figure 2) and the water balance obtained (in mm/year): precipitation 2555.32; evapotranspiration (ET) 1370.51; potential evapotranspiration 1435.84; observed discharge 756.99; simulated discharge 
835.59. For total discharge, interflow represents the $30.98 \%$, base flow the $56.58 \%$ and direct runoff the $12.46 \%$, which maintains a similar behaviour of calibration results.

It can be seen in Figure 2 that the validation covers years with different hydrological balances.

\section{Conclusions}

In a rainfall-runoff conceptual model, the reliability of the results depends on the input data quality, the model structure and the calibration process [6]. For our case study, we have argued that the main restraints are the lack of information (hydroclimatic, edaphologic and geologic) and the irregularities in terms of its continuous quality control.

This study is one of the first attempts in Central America of proving the hydrological significance of cloud forest upstream of dry areas by using a conceptual distributed hydrological model.

The temporal validation has confirmed that the correction factors obtained (considering the lack of data) for the Las Minas station can capture "satisfactorily" the hydrological behaviour of the Teculután catchment.

\section{Acknowledgements}

Primary funding for the research and development presented in this paper was provided by grants from MAE program 2003-2005 and PCI A/2428/05 and A/6014/06 from the Spanish International Cooperation Agency AECI, and National Plan I+D Spain CGL2005-06219/HID. The authors thank Defensores de la Naturaleza, Instituto de Agricultura, Recursos Naturales y Ambiente (IARNA-URL) and Instituto Nacional de Bosques INAB in Guatemala for assistance in the field and logistical support. The parameter maps used in this work were processed with the collaboration of Juan José Montoya.

\section{References}

[1] Brown, M.B., de la Roca, I., Vallejo, A., Ford, G., Casey, J., Aguilar, B. \& Haacker, R. A valuation analysis of the role of cloud forests in watershed protection: Sierra de las Minas Biosphere Reserve, Guatemala and Cusuco National Park, Honduras. RARE / FDN / Fundación Ecologista Hector Rodrigo Pastor Fasquelle / TNC: Guatemala, pp. 1-134, 1996.

[2] Bruijnzeel, L.A., Hydrology of tropical montane cloud forests: a reassessment. Land Use and Water Resources Research 1, pp. 1.1-1.18, 2001.

[3] Bruijnzeel, L.A., Burkard, R., Carvajal, A., Frumau, A., Köhler, L., Mulligan, M., Schellekens, J., Schmid, S. \& Tobón, C., Hydrological impacts of converting tropical montane cloud forest to pasture, with initial 
reference to northern Costa Rica. Final Technical Report DFID-FRP Project no. R7991. pp. 1-52, 2006.

[4] FDN. III Plan Maestro de la Reserva de Biosfera Sierra de las Minas. FDN: Guatemala, pp. 1-81, 2003.

[5] Francés, F., Vélez, J.J. \& Vélez, J.I. \& Puricelli, M., Distributed modelling of large basins for a real time flood forecasting system in Spain. In: Proceedings Second Federal Interagency Hydrologic Modeling Conference, Las Vegas, USA, CD Format, 2002.

[6] Francés, F., Vélez, J.I. \& Vélez, J.J., Split-parameter structure for the automatic calibration of distributed hydrological models. Journal of Hydrology 332, pp. 226-240, 2007.

[7] Frumau, K.F., Bruijnzeel, L.A. \& Tobon, C., Hydrological measurement protocol for montane cloud forest. Annex 2, Final Technical Report DFIDFRP Project R7991. Vrije Universiteit: Amsterdam, pp. 1-105, 2006.

[8] Holder, C.D., Fog precipitation in the Sierra de las Minas Biosphere Reserve, Guatemala. Hydrol. Process. 17, pp. 2001-2010, 2002.

[9] Holder, C.D., Rainfall interception and fog precipitation in a tropical montane cloud forest of Guatemala. Forest Ecology and Management 190, pp. 373-384, 2004.

[10] Hölscher, D., Köhler, L., van Dijk, A.I. \& Bruijnzeel, L.A., The importance of epiphytes to total rainfall interception by a tropical montane rain forest in Costa Rica. Journal of Hydrology 292, pp. 308-322, 2004.

[11] Puricelli, M., Estimación y distribución de parámetros del suelo para la modelación hidrológica. PhD dissertation. Universidad Politécnica de Valencia, Departamento de Ingeniería Hidráulica y Medio Ambiente: Spain, pp. 1-435, 2003.

[12] SINAFIP \& EDESA. Estudio de factibilidad y diseño final para el ordenamiento y plan de manejo integrado del área de la cuenca del río Teculután, comprendida en el municipio de Teculután, departamento Zacapa. SINAFIP - BID, contrato No. 117-2003. Tomo I, Cap 1-11 y Anexos, pp. 1-269, 2004.

[13] Vélez Upegui, J.I., Desarrollo de un modelo hidrológico conceptual y distribuido orientado a la simulación de las crecidas. $\mathrm{PhD}$ dissertation. Universidad Politécnica de Valencia, Departamento de Ingeniería Hidráulica y Medio Ambiente: Spain, pp. 1-266, 2001. 